\title{
A CROSSROADS OF CULTURES IN A MOSAIC OF REGIONS? THE EARLY VISIGOTHIC REGNUM FROM THE PERSPECTIVE OF SMALL FINDS
}

\section{JOAN PINAR GIL}

\begin{abstract}
A survey is proposed on two insufficiently researched aspects of late fifth-century clothing in southern Gaul and Hispania: multiculturalism and regionalism. Focusing on both aspects improves the understanding of a number of phenomena recorded in funerary contexts.
\end{abstract}

Key words: Visigothic period, clothing, cemeteries, Hispania, southern Gaul.

\section{Introduction}

For many years, archaeological research on the West in the Visigothic period has relied upon the study of small finds of clothing (Barrière-Flavy 1892; Åberg 1922; Zeiss 1934; James 1977; Ripoll 1991; Bierbrauer 1994; Ebel-Zepezauer 2000; Sasse 2000; Hernandez 2001; Stutz 2003; López Quiroga 2010). The analysis of such objects has gone through an important process of renewal in the last few decades. Nonetheless, the research on the early Visigothic kingdom is still conditioned by certain long-lasting historiographical myths, some of which involve archaeology directly: the existence of a general lack of Visigothic-period archaeological remains in southern Gaul and of a coherent and homogeneous settlement area of Visigoths in central Spain, and the coexistence of two sharply distinguished geographies, a popular one and an aristocratic one. Some of these concepts just seem to be outdated, when considering the general features of clothing accessories in southern Gaul and Hispania, their dating and the pattern of their dissemination.

This paper does not intend to discuss in depth every one of the above-mentioned research problems. Instead, I will concentrate very briefly on what I consider to be two key topics for a better understanding of the global picture in the early Visigothic kingdom: multiculturalism and regionalism.

\section{Cultural diversity}

A number of scholars have dealt with the topic of the multiplicity of cultural traditions taking part in the moulding of Visigothic-period clothing in southern Gaul, and especially in Spain (Zeiss 1934; Bierbrauer 1980; Ripoll 1985; 1991; 1998; 1999; Sasse 2000;
Ebel-Zepezauer 2000). However, the perspective used to focus on defining some kind of barbarian-Mediterranean duality in its last consequence implied a more or less explicitly formulated ethnic attribution, that is, Visigothic or Roman.

A careful examination of small finds from the area of the early Visigothic regnum shows that such a reductionist picture does not fit the complexity of the archaeological record. Perhaps the clearest problem is posed by the examination of traces of barbaricum-originated clothing traditions in southern Gaul and Spain. Here we have to deal with north Pontic and middle-Danube inspired clothing accessories, but also with elements that originated in northern Gaul or in the Rhine area, which reached the territories of the Visigothic kingdom as well.

All of these objects are documented in southern Gaul and Hispania by the mid-fifth century, during what can be labelled as the first phase of intense inhumation habillée (clothed inhumation) in many cemeteries. At that time, north Pontic traditions of dress can be observed in some Narbonensis I cemeteries (Fig. 1), such as Le Vernet-Le Mouraut, Estagel-Les Tombes, MolandierBénazet and Maguelone (Catalo et al. 2008; Paya 2010; Lantier 1943; 1949; Cazes 2009; Legrand-Garnotel 2004). Some stray or settlement finds, located mainly in Narbonensis and the Garonne valley, may be added to this group: Albias, Séviac, Bragayrac, Quarante (Kazanski 1994, Figs. 1.1; 3.1; 3.3; 8.1; 1998, Figs. 3.1; 4.1; 4.3; 5.1; Massendari 2006, pp.126-127, Fig. 39). Danubian imports or, most probably, local productions after middle-Danube prototypes, can be identified in this period, in sites such as Herpes and Routier (Delamain 1892; Toulze, Toulze 1983). The latter can be linked to a group of necropolises scattered between Toulouse and Carcassone that will be

\section{II}

PARADE

OF SHIELDS

AT THE

CROSSROADS

OF GERMANIC

CULTURES 


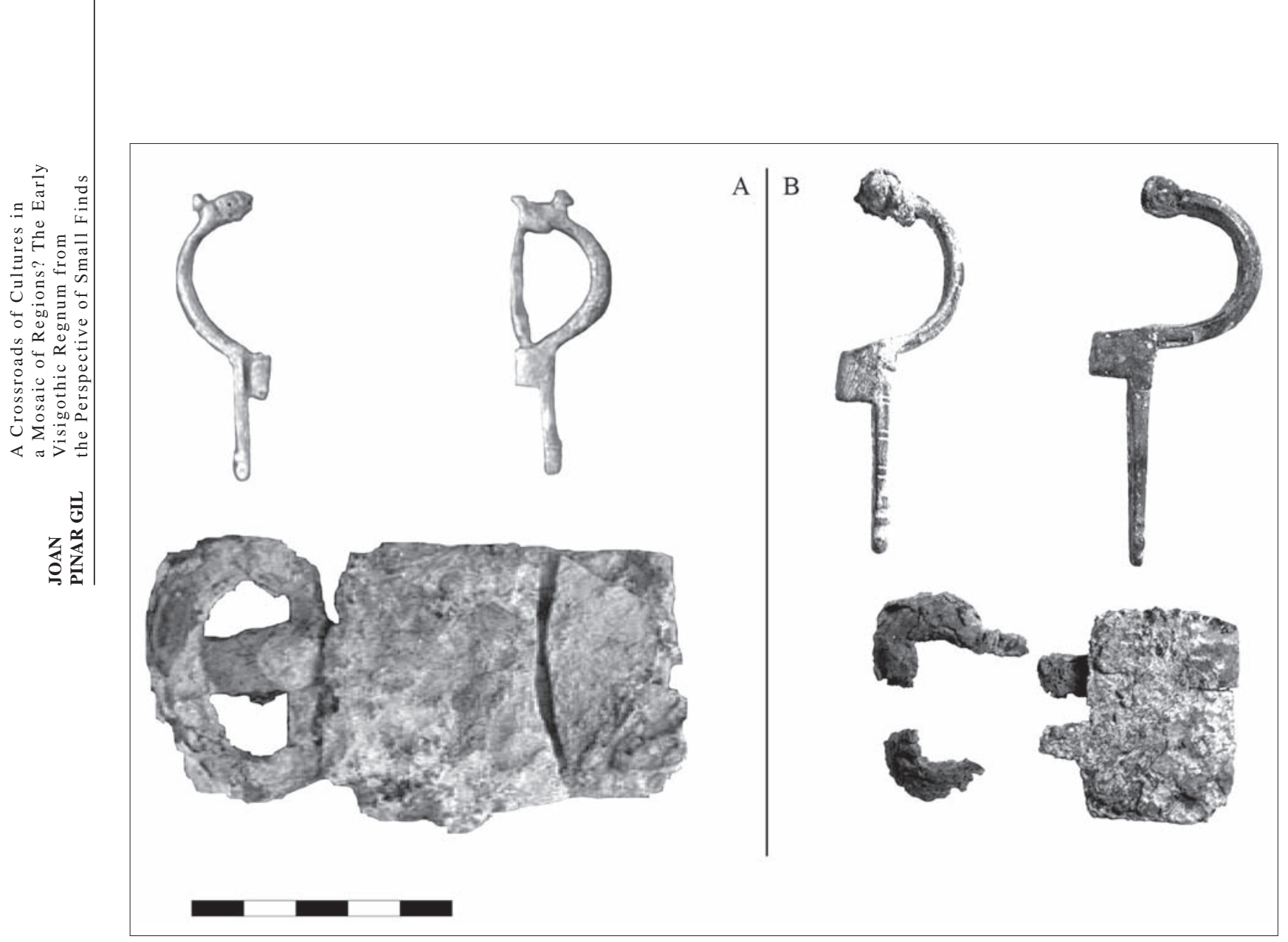

Fig. 1. Examples of early female graves dressed after north Pontic traditions in Narbonensis: A Le Mouraut, grave 83 (after Paya 2010); B Estagel, grave 118 (photographs by J. Pinar. I want to thank Patrick Périn and Christian Landes for study and publication permission).

discussed later. Herpes keeps appearing as a somewhat isolated enclave, with a very genuine mixture of elements that originated both in the middle Danube and Anglo-Saxon territories. During that period, southwest Spain, the Lusitania province, seems to be the main area of concentration of north Pontic and middle-Danube small finds in the Iberian Peninsula. Let us quote as the clearest examples the fibulae from the castle of Sines, Merida and F. Calzadilla's private collection, and the sword-furnished grave of Beja. To this group could be linked maybe a lead model and a belt buckle, probably found somewhere in southern Spain: they both find their best counterparts in the Ponto-Danubian territories (Pinar 2011, Figs. 1-3; 6B.1, with earlier literature).

Further related finds appear occasionally in northwest Spain and in the centre of the Castilian plateau. In this last territory, they may be broadly contemporary to a Hispanic-based group of female graves dressed with locally produced Blechfibel type bow brooches (Fig. $2.32,79)$. The appearance of such a group, named I/ II in earlier papers (Pinar 2010a; 2010b), may be slightly later than the earliest Ponto-Danubian elements recorded in Narbonensis and Lusitania. That is indeed difficult to assert, due to the lack of such graves in southern Gaul, where only a few of the ob- jects characterising the central Spanish group have so far been identified. It is very likely that this group and the earliest south-Gaulish clothing combinations with crossbow brooches after the north Pontic fashion were partially contemporary, both of them having an upper chronological limit of about $500 \mathrm{AD}$.

No clear difference between the dissemination area of north-Pontic, Danubian and northern Gaul-Rhineland elements can be appreciated. They all occur in the same regional contexts, frequently also in the same sites. Distinguishing between Pontic and Danubian influences appears to be especially difficult, as they seem to be intimately bound from the very beginning. Maguelone grave 2187 (Legrand-Garnotel 2004, Fig. 59) appears to be a good example, as it contained a combination of a Wielbark culture descendant crossbow brooch and a middle-Danube radiated bow brooch, reproducing a mainly northern Black Sea type of clothing (Mastykova 2007, Figs. 7.4; 8.1; 8.6; Pinar, forthcoming). Another interesting case is the aforementioned pair of brooches from Chasseneuil-sur-Bonnieure grave 89 (Poignant 2010, Fig. 3), which appears to be a mixed form between middle-Danube Prša-Levice fibulae and mainly north-Gaulish-Rhenanian productions of Bulles-Lauriacum-Sindelfingen type. 


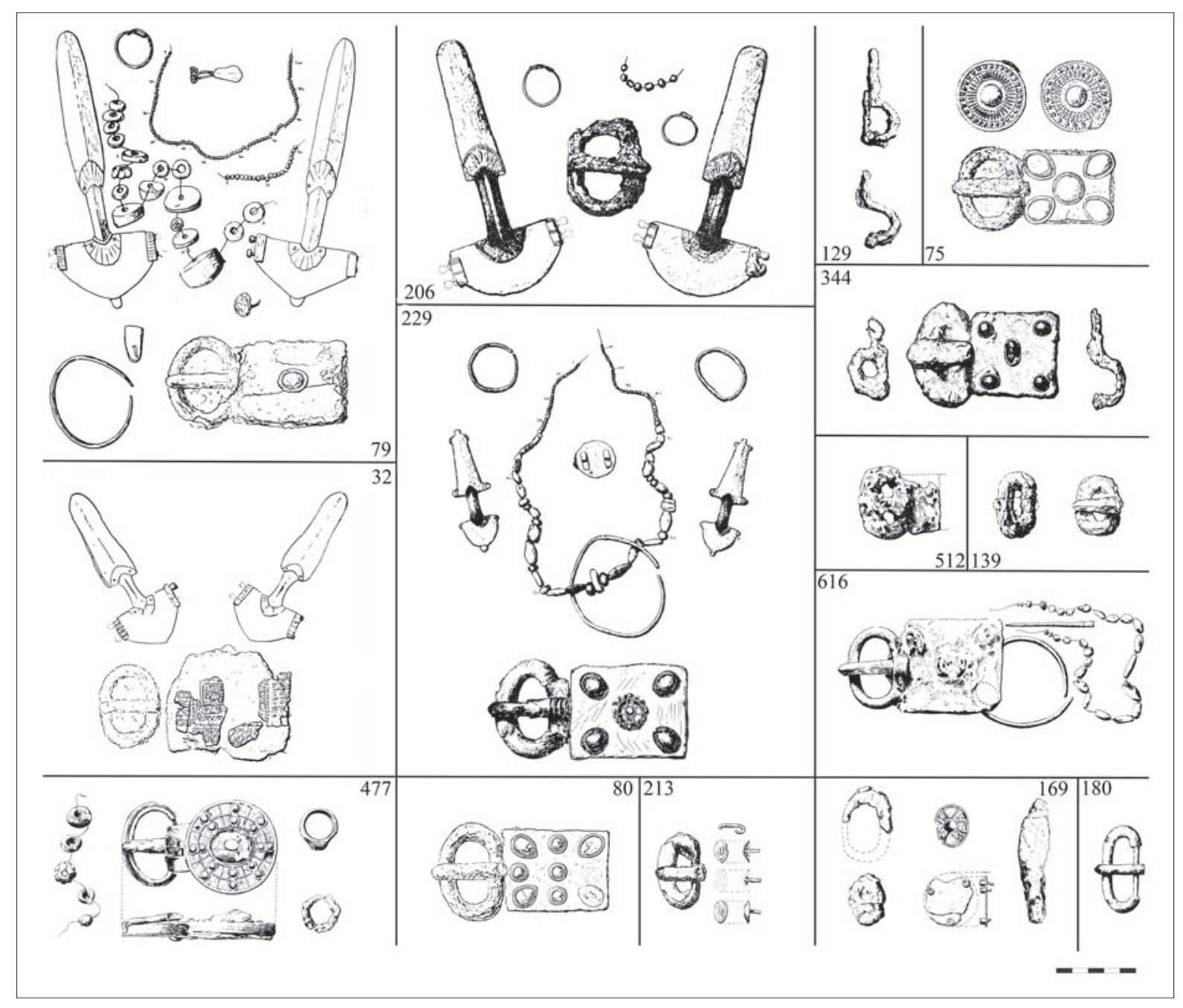

Fig. 2. Duratón: examples of graves belonging to the first phase of generalised clothed inhumation (after Molinero 1971).

A general look at the graves of the first phase of intense clothed inhumations in the better-researched cemeteries shows indeed a remarkable mixture of clothing traditions already (Fig. 2). Thus, female graves with Blechfibeln, so-called nomadic earrings and graves after north Pontic clothing traditions appear in the first phase of frequent clothed inhumations, in cemeteries such as Duratón, and to a lesser extent Boadilla de Arriba (Molinero 1948; 1971; Catalán, Rojas 2010; Pinar 2011). In some cases, influences from northern Gaul or from the Rhineland can also be recognised, for example in the earliest graves with repoussé-decorated disc brooches (Fig. 2.75) at Le Mouraut and Duratón (Catalo et al. 2008, pp.278-279; Molinero 1948, Pl. XXVI.3; 1971, IV.1). In the latter cemetery, grave 427 (Fig. 3) was furnished with a 'Merovingian' combination of two small cloisonné disc brooches and a simple iron belt buckle (Molinero 1971, Pl. XXXVI.2); it should be dated to this period or to the one immediately after. A number of early small bow brooches of the so-called Numancia type (Fig. 2.229, 4C) can be regarded as the result of further northwestern influence, as they probably represent a local form based upon fibulae of Bulles-Lauriacum-Sindelfingen type (Pinar, 2012). They occur at Duratón, Estagel and Espirdo. A mid-to-late fifth-century radiated bow brooch found at Deza, grave 8 (Taracena 1927, Pl. 16.8; Zeiss 1934, Pl. 5.6) can certainly be regarded as an import from the upper Rhine region. Danubian-inspired female dresses are also recorded in this cemetery; however, they seem to appear somewhat later, not before the second third of the sixth century. A similar context can be attributed to the Nieder-Florstadt type brooch corresponding to a stray find at Ouveillan, Champ de l'Âne (Hernandez 2001, num. 452). In the nearby cemetery of Le Chambard, some mid-sixth century objects linked to Ponto-Danubian traditions have been recorded (Bouisset 1973).

Further examples of the coexistence of traditions of dress from different Central or East European regions can be found at Madrona and Carpio de Tajo (Molinero 1971; Sasse 2000). In the former, a radiated bow fibula connected to Groß-Umstadt type forms was recorded as a surface find (Fig. 4D). It may probably be regarded

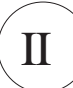

PARADE OF SHIELDS AT THE CROSSROADS OF GERMANIC CULTURES 


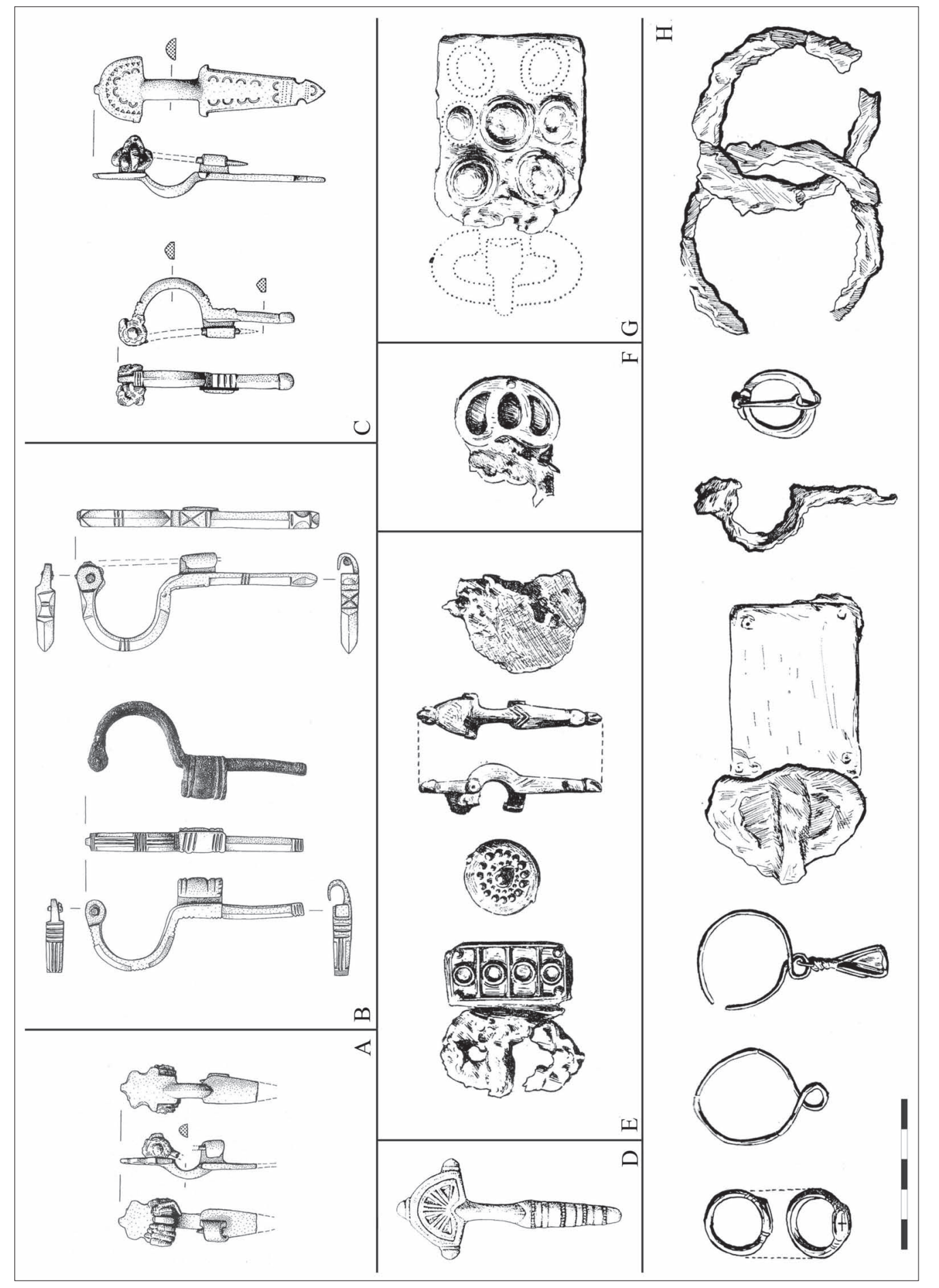

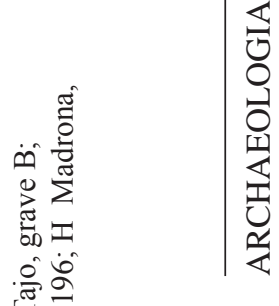

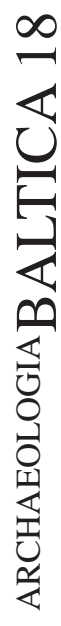

$\%$

ปี

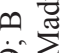

a

हैं

造

ชี ฮี

密

$\varangle$

过

旁

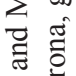

율

요다

윰

过

政

है क⿺

ชै

远

定

영

각유

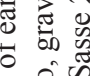

论

寅宁

炛.융

ن.

\section{II}

PARADE

OF SHIELDS

AT THE

CROSSROADS

OF GERMANIC

CULTURES 


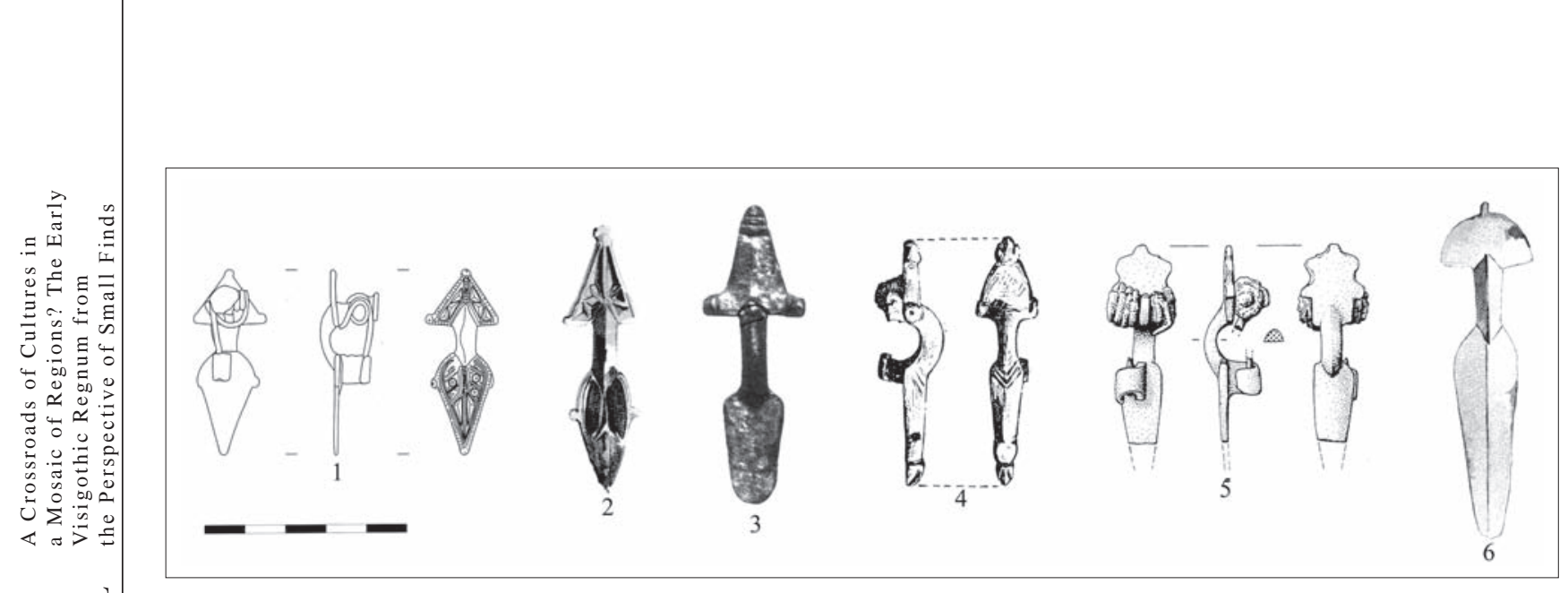

Fig. 5. Fifth-century brooches after Central European prototypes: 1 Chasseneuil-sur-Bonnieure, grave 89; 2 Herpes; 3 find spot unknown, probably of Spanish provenance; 4 Madrona, grave 24; 5 Carpio de Tajo, grave 119; 6 Herpes (after Poignant 2010; Delamain 1891; Zeiss 1934; Molinero 1971; Sasse 2000).

grave 110 to north Pontic traditions appear to be especially strong. Even in this case, however, we can see the presence of a bow fibula of Numancia type, developed locally after Central-West European prototypes.

The Nieder-Florstadt type brooches from Madrona 24 and Carpio de Tajo 119 lead us to a further point of interest. They both share a morphological feature that distinguishes them from their eastern and northernmost parallels: their footplates are shaped in a form half-way between a tongue and a heart. This form repeats itself in a number of mid-fifth century brooches from the territories of the Visigoth kingdom (Fig. 5), as is shown by examples from Herpes, Chasseneuil-sur-Bonnieure, and probably a Spanish find lacking an exact provenance (Delamain 1892, Pl. VI.22, VI.25; Poignant 2010, Fig. 3; Zeiss 1934, Pl. 2.8). There is little doubt that we are dealing with a group of imitations of Central European prototypes made by local workshop(s). The typological milieu of these objects appears to be a good example of the extent of diversity that inspired the local production of the Visigothic kingdom: we can identify the imitation of north Gaul-Rhineland origin brooches together with forms deeply rooted in middle-Danube traditions, such as the Prša-Levice and Carnuntum-Oslip types. A similar phenomenon, as has been said before, is also visible in the close formal relationship between Bulles-Lauriacum-Sindelfingen and Numancia brooches.

According to an extremely reductionist way of reasoning, what is not barbarian by origin, that is, what shows no straightforward connection with the Central and East European barbaricum, could be regarded as Roman. But the definition of 'Roman' clothing components in the Visigothic kingdom also appears to be not so simple: here we are dealing with local or regional production, Mediterranean or Western-scale distributed ones, even with imports from the eastern Medi- terranean. To what extent a certain category should be regarded as more Roman than other ones remains unclear. Furthermore, demonstrating that such objects were produced and used exclusively by late fifth-century western 'Romans' is far beyond the possibilities of present-day archaeological records.

During what I have repeatedly referred to as the first phase of intense inhumation habillée, women buried clothed after certain Mediterranean traditions are almost completely missing. This is an interesting point for discussion, as they appear with noticeable frequency in the sixth century, and become hegemonic by the beginning of the seventh century. Among the few hypothetical examples of mid-fifth century, not specifically barbarian female clothing, we can quote Madrona grave 154 (Molinero 1971, Pl. LXXV.2). However, the grave's inventory has not been verified so far, and its disc brooch cannot be dated to a more precise time between the second half of the fifth century and the second third of the sixth century. The typology of the repoussé-decorated fibula, however, shows strong links with northern Gaul, Britain and the Rhineland. A number of female graves furnished with a big composite belt buckle and lacking any fibula (Fig. 2.80, 477, 616) could be linked to Late Roman traditions, as is shown convincingly by a number of authors (Martin 1991; Quast 1999). But this type of clothing is also well known in the middle-Danube and north Pontic regions, and an examination of the archaeological contexts relating to the finds in the West does not solve the problem of their cultural attribution: in some cases, they may appear next to some types of barbaricum-inspired clothing; in other cases they are found in backgrounds lacking any clear link with any kind of barbarian material culture. In such a context, Duratón grave 477 appears to be very revealing: being the earliest record of this type of clothing in the whole region, the belt buckle appears to be a Mediterranean 


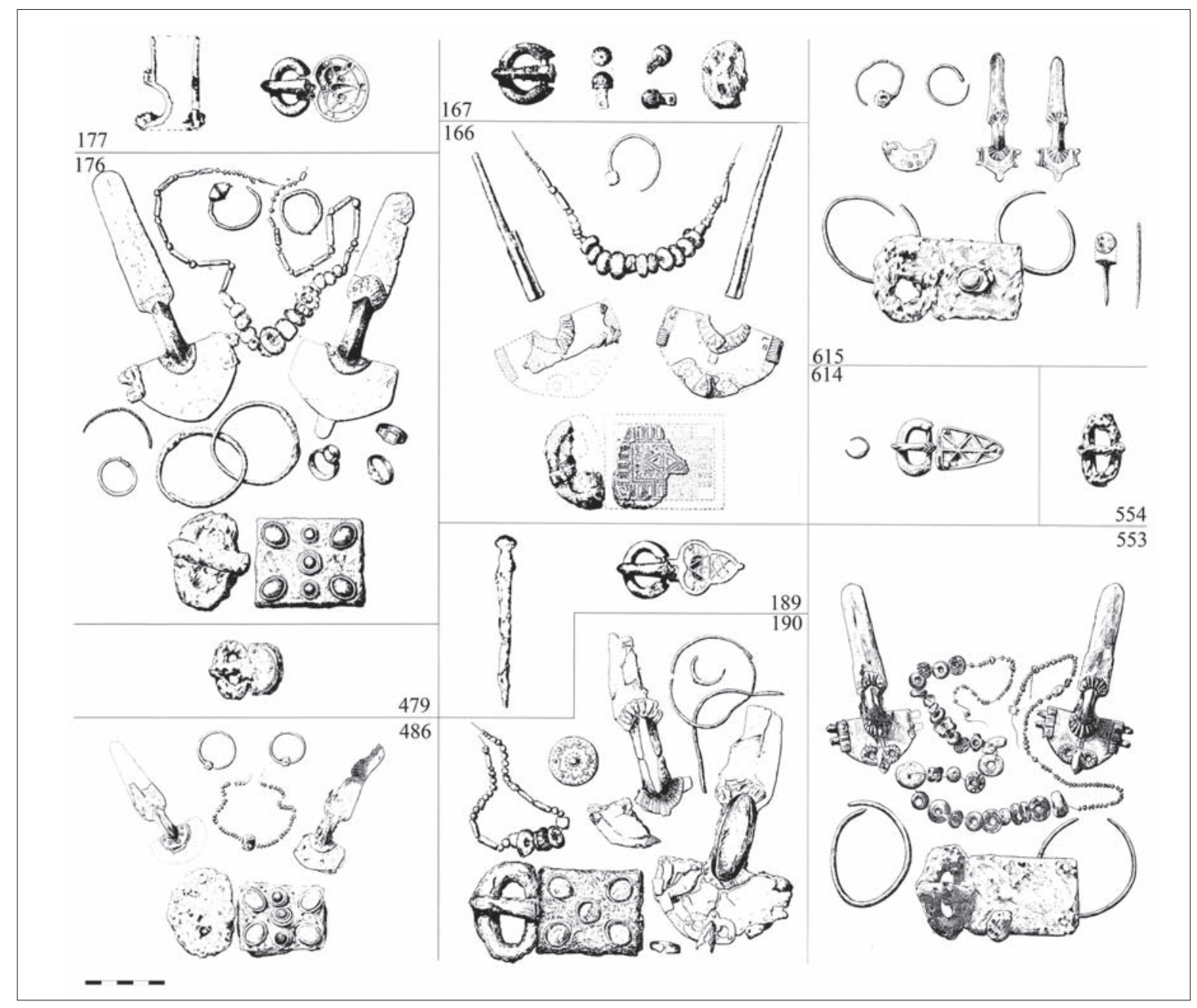

Fig. 6. Duratón: examples of pairs of graves displaying Ponto-Danubian female clothing accessories (after Molinero 1971).

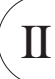

PARADE OF SHIELDS AT THE CROSSROADS OF GERMANIC CULTURES counterpart of a well-known Ponto-Danubian typology (Koch 1999; Pinar 2011).

There is little doubt that the funerary practice of burying the dead with everyday life's adornments and accessories shows a close relationship between barbarian objects and clothing traditions during the second half of the fifth century. Thus, the general picture points to a link between such innovations and the presence of barbarian populations in southern Gaul and Hispania. Should we accept this hypothesis, then we might find the late fifth-century 'Romanness' in some of the majority of burials lacking any grave goods: in fact, they represent the clear majority even in every cemetery with a strong presence of barbarian clothing traditions. Nevertheless, we should avoid the reductionist equation no clothing accessory or grave goods = Roman individual. From recently carefully researched cemeteries such as Le Mouraut and Bénazet, we know that fifth-century artificial skull deformation, a practice attributable, in this period and territory, to East European barbarians, occurs in graves without any metal clothing object or any grave goods (Cazes 2003; Catalo et al. 2008; Paya 2010). On the other hand, inhumation habillée occurs occasionally in cemeteries where barbarian influences never appear at all. Indeed, many examples conveyed both by archaeology and written witnesses show that it was never an unusual practice throughout the Mediterranean basin, in spite of the advice by Church fathers and the regulations of the earliest known liturgical compilations (Pinar, Turell 2007).

A certain 'Romanness' of dress is shown during the second half of the fifth century by male graves. When focusing our attention on cemeteries where the early presence of barbarian dressing traditions is stronger, we find that a number of Mediterranean or West European buckles appear in close proximity to female inhumations dressed after the middle-Danube or northern Black Sea aristocratic fashion (Fig. 6). In cemeteries like Duratón, it is not unusual to find Mediterranean or Western-style clothed men lying next to female inhumations dressed after the barbarian fashion. In- 

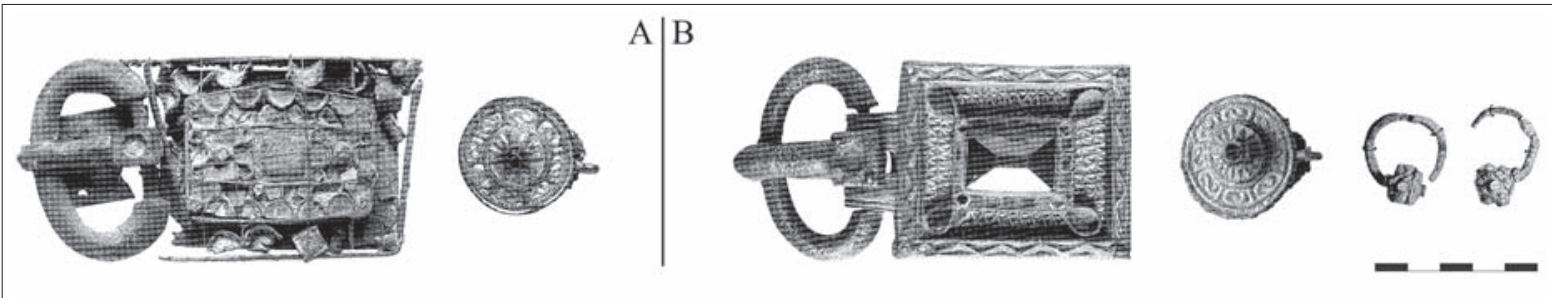

Fig. 7. Carpio de Tajo: examples of graves furnished with composite belt buckles and disc brooches. A grave 204; B grave 203 (after Sasse 2000).

terpreting such pairs of broadly contemporary graves as traces of nuclear families, as is already proposed, is decidedly tempting (Pinar, Ripoll 2007, pp.74-80). Among the male graves forming part of such pairs, Duratón grave 614 appears to be the best example of a mixture of Mediterranean and East European clothing elements, as its cloisonné belt buckle and croissantshaped earring show respectively. No male belt recorded so far can be specifically related to Central or East European traditions, the eventual barbarian origin of such men is demonstrable on the basis of the remains of the clothing. A similar consideration deserves the likely presence of two combinations of cloak brooches and belt buckles (Figs. 2:169; 6:177) in the late-fifth century Duratón (Pinar 2010c, p.244ff).

Thus, the small clothing finds convey a general picture where a multiplicity of cultural traditions coexisted. This picture did not change significantly during the following decades, when Ponto-Danubian, Merovingian and Roman-Mediterranean influences are also to be seen. The balance between these components, however, changed as time went by. North-Pontic relatable dressing combinations with crossbow brooches disappeared after the first third of the sixth century; Danubian-inspired female dressing thus became hegemonic in 'eastern barbarian' clothing. Imports from northern Gaul were increasingly present in the territory of Aquitaine, while Danubian-inspired objects became extremely rare after the first third of the sixth century. A connection with the new political scenario set out by the Frankish conquest of Aquitania can reasonably be suggested.

One of the most interesting changes in the balance between the various cultural traditions is the growth of combinations based on Mediterranean-wide fashion, especially in central Spain. They appear from the midsixth century on, but with some regional differences in the rhythm of the process. The clearest examples are combinations consisting of a big composite belt buckle and a disc or zoomorphic brooch (Fig. 7). Iconography furnishes a number of examples of how such a combination was deeply rooted in the Late Roman and Byzantine Mediterranean basin (for example, Baldini 1999,
Fig. 58). Graves dressed in this way tend to appear in grave groupings where contemporary Danubian-influenced female dress is attested: can they be interpreted as the result of an expanding tendency towards clothed inhumation, or as a further, mediterraneanising step in the evolution of barbarian-inspired dress?

\section{Regional-based clothing types and evolution}

At least five regions with particular clothing types can be traced, their identification depending lastly on the state of archaeological research in each region and on the predominant funerary rite: only the areas with a sufficient number of explored clothed inhumations may enable the identification of specific regional clothing types and the tracking of their development through time.

The clearest distinct regions that we can identify on the basis of clothing accessories are the present province of Segovia in central Spain (Fig. 8.1-6), the central part of the Roman tract linking the cities of Caesaraugusta and Emerita Augusta (the provinces of Toledo, Madrid and Guadalajara) (Fig. 8.7-18), the 'Silver Route' in western Spain (the provinces of Badajoz, Cáceres, Salamanca and Zamora) (Fig. 8.19-24), the surroundings of Via Domitia in Narbonensis (Fig. 8.25-33), and the Charente region in northern Aquitania II (Fig. 8.3441). As can be seen, most of them are related to a major communication axis. In each of them, the above-mentioned characteristic mixture of elements defining a number of funerary contexts in the Visigothic kingdom can be observed, but presenting differences both in the typology of the accessories and the way of combining them (Fig. 9).

Thus, in the Segovia province, we may refer to the overwhelming prominence of middle-Danube origin clothes. Already attested to in the first period of intense inhumation habillée, a Danubian-influenced female dress will be a constant feature for at least four generations, from the last third of the fifth century to the third quarter of the sixth century, in the biggest cemeteries of 


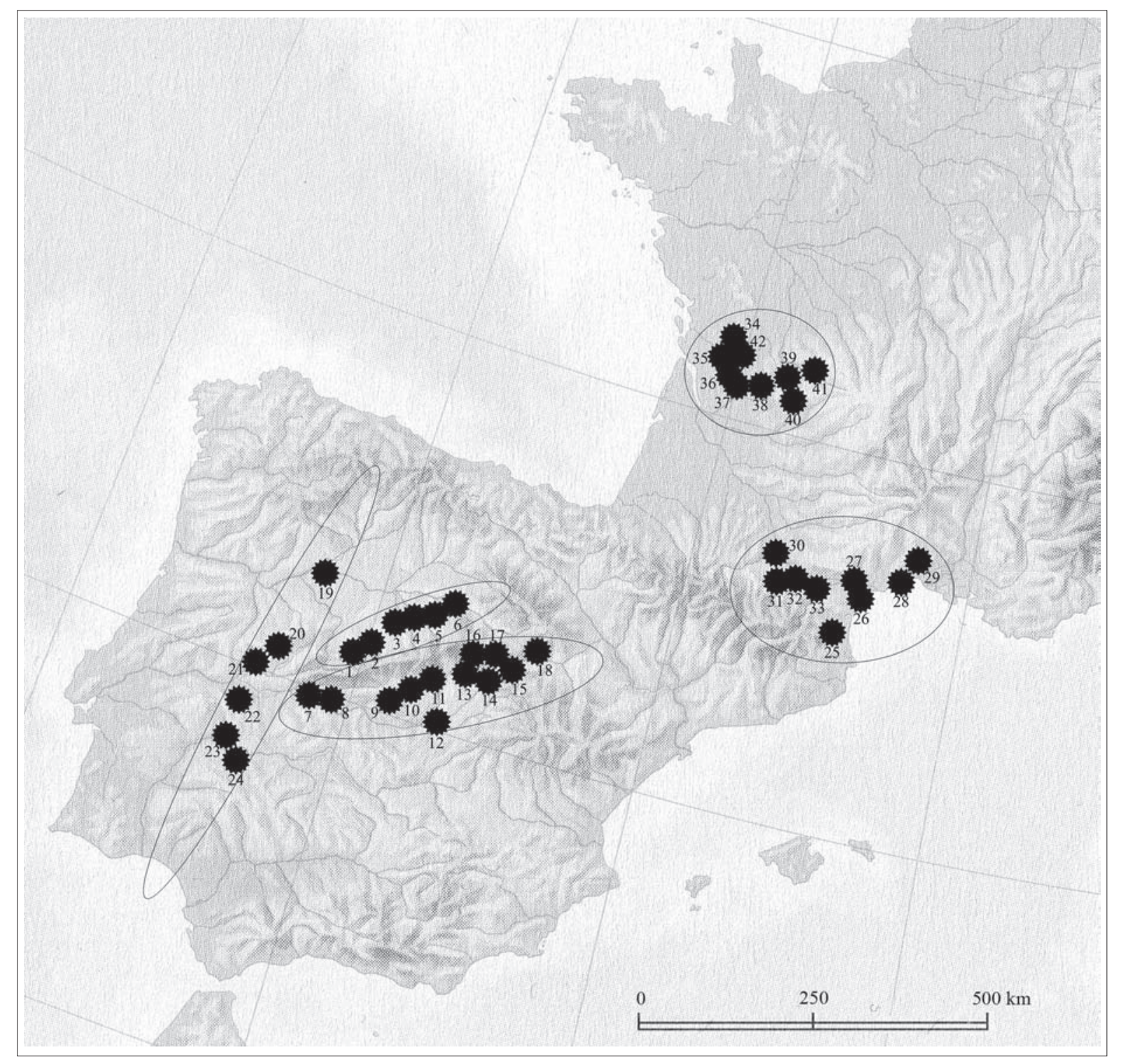

II

PARADE

OF SHIELDS AT THE

CROSSROADS OF GERMANIC CULTURES

Fig. 8. The main areas of regional clothing types and their most characteristic find spots. A. Segovia: 1 Madrona; 2 Espirdo; 3 Aguilafuente; 4 San Miguel de Neguera; 5 Duratón; 6 Castiltierra. B. Toledo-Madrid-Guadalajara: 7 Castillo de Bayuela; 8 Carpio de Tajo; 9 Illescas; 10 Pinto; 11 Gózquez de Arriba; 12 Cacera de las Ranas; 13 Camino de los Afligidos; 14 Santos de la Humosa; 15 Azuqueca; 16 Daganzo de Arriba; 17 Alovera; 18 Espinosa de Henares. C. Badajoz-Cáceres-Salamanca-Zamora: 19 Zamora; 20 Zarza de Granadilla; 21 Galisteo; 22 Cáceres; 23 Barbaño; 24 'Tierra de Barros'. D. Pyrénées-Orientales-Haute-Garonne-Aude-Hérault: 25 Estagel; 26 Sérignan; 27 Beissan; 28 Maguelone; 29 Lunel-Viel; 30 Toulouse; 31 Le Vernet; 32 Molandier; 33 Routier. E. Charente-Maritime-Charente; 34 Asnières-laGiraud; 35 Saintes; 36 Biron; 37 Chadenac; 38 Criteuil-la-Magdeleine; 39 Roullet-Saint-Estèphe; 40 Ronsenac; 41 Chasseneuil-sur-Bonnieure; 42 Herpes.

the region, such as Duratón (where pre-500 AD clothes after Danubian fashion appear exclusively), Castiltierra, Aguilafuente and Madrona. During the decades immediately before and after $500 \mathrm{AD}$, a Danubian-origin dress with a pair of big Blechfibeln worn on both sides of the chest, and a big composite belt buckle, appears to be typologically quite close to the Danubian prototypes. From the second third of the sixth century on, however, the central Spanish Blechfibeln underwent a formal technical evolution: the middle-size exemplars became cast, while the bigger ones were replaced by local types of radiated, carved bow brooches deriving lastly from Danubian traditions.

In this region, combinations of clear northern Black Sea origin are not numerous: this type of clothing may have been replaced by middle-Danube origin ones quite quickly. The example of Duratón grave 344, a north-Pontic reminiscent combination with two crossbow brooches dating from the last third of the fifth century, laid close to grave 327 , a typical combination with brooches derived from Blechfibeln and dating from the second third of the sixth century, furnish some evi- 


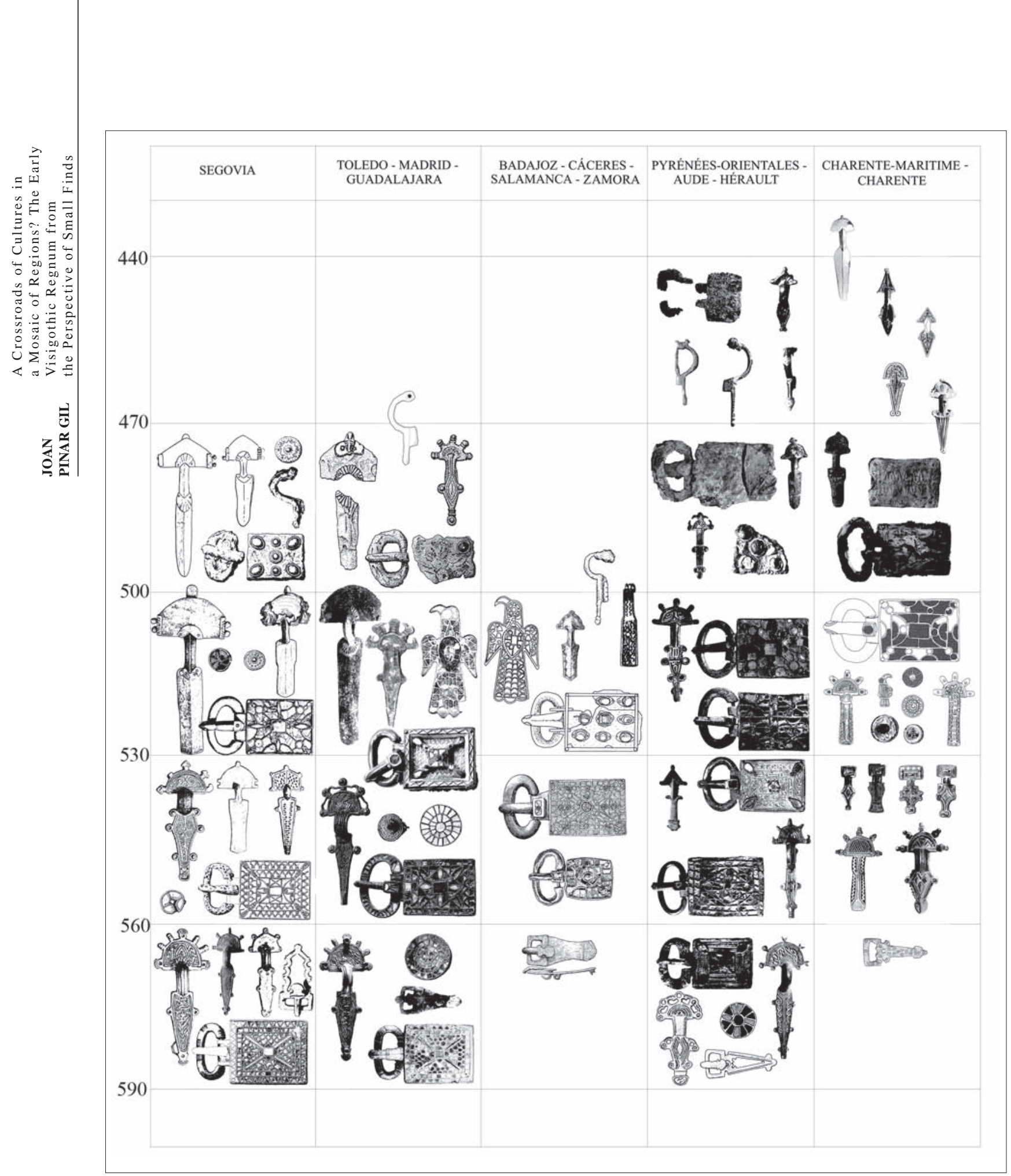

Fig. 9. Diachronic regional sequences showing the evolution of clothing accessories in southern Gaul and Hispania (after Delamain 1892; Barrière-Flavy 1892; Paya 2010; Pinar 2011, forthcoming; Poignant 2010; Lantier 1943, 1949; Molinero 1971; Lucas, Viñas 1977; Ardanaz 2000; Catalán, Rojas 2010; Oñate 2010; Raynaud 1986; Donoso, Burdiel 1970; Fernández de la Mora 1974; Gohlke, Neumayer 1996; Périn 1991; Sasse 2000; Foreigners in Early Medieval Europe: http:// www2.rgzm.de/foreigners/frame.cfm?Language=UK).

dence about what the destiny of such dress might have been. At least in that region, Pontic traditions seem to be already danubised after one or two generations. The above-mentioned early brooches found at Madrona, and some Numancia-type brooches from Duratón and Espirdo, may be the few forms that can be related to northern Gaul or Rhineland production.
The differences between this region and the nearby central part of the Emerita-Caesaraugusta tract are remarkable, in spite of the similar typological backgrounds displayed by the clothing accessories recorded in both territories. In this region, 'eastern barbarian' clothing is represented by graves furnished with a single Blechfibel: such dress is almost absent in the Segovia region, except for a late, possibly second third of the sixth 
century, not verified example from Duratón grave 373 (Molinero 1971, Pl. XXXIII.1). The limited available data points to the brooches being worn on one shoulder or on the skeleton's pelvis. The latter position finds no sure counterpart in the territory of Segovia. The use of just one Blechfibel occurs far more frequently in the north-Pontic area than in the middle Danube, and the pelvic position of the brooches, although rare, can be traced to Chernyakhov culture territory (Mastykova 2007, p.213; Hopkalo 2011, pp.28-29).

Yet another difference between the two main regions of clothing of central Spain can be observed during the late fifth century and the early sixth century. In the southernmost one, we can mention the remarkable quantity of finds of early radiated bow brooches with carved decoration, attributable lastly to middle-Danube traditions of dress. Related brooches do not appear in the Segovia area prior to the second third of the sixth century, with the sole likely exception of Madrona grave 41 (Molinero 1971, Pl. LXVIII.2). Another typological feature of this region is the considerable number of eagle-shaped cloisonné brooches; the only example dating back prior to $500 \mathrm{AD}$, Talavera de la Reina (?), should have been found in this region. However, even the later examples, dating to the first third of the sixth century, are rare in the northernmost territories. Also the composite belt buckles of Azután type show a similar dissemination pattern, the finds south of the Guadarrama mountain range being overwhelmingly more frequent than north of it.

Yet another region with characteristic elements of clothing can be identified in Hispania, in spite of the dramatically fragmentary archaeological documentation. The finds located in the surroundings of the Silver Route, connecting Emerita Augusta with Asturica in northwest Spain, throughout the provinces of Badajoz, Cáceres, Salamanca and Zamora, show a somewhat different evolution. We find two principal types of object here: crossbow brooches and eagle-shaped cloisonné brooches, both categories being remarkably homogeneous on a regional basis, as the decoration of the former and the morphology of the latter show. Female dress combinations along the Silver Route do not seem to survive after the end of the first third of the sixth century, thus marking yet another difference with regard to central Spanish regional-based clothing elements.

The most easily recognisable region of independent clothing in southern Gaul is located in the territory of Narbonensis I, or more exactly on the coast, in the present-day départements of Pyrénées-Orientales, Aude and Hérault. Just as in Spain, the spread of female dress combinations and elements is connected with a major
Roman transport axis, the Via Domitia. The main element in this region is the wide use of radiated bow brooches, frequently integrated in dress combinations consisting of a single fibula, worn on one shoulder or on the upper thorax, and a composite belt buckle. Such dress is recorded during the first three quarters of the sixth century. Sharply distinguishable from contemporary dominant female dress both in the Segovia province and along the Silver Route, it nonetheless shares a number of features with finds along the Emerita-Caesaraugusta road. Dresses with pairs of radiated bow brooches are also known in Narbonensis from the late fifth century: this is a feature shared with the EmeritaCaesaraugusta and later the Segovia regions.

The use of radiated bow brooches in Narbonensis dates back to the mid-fifth century, as is shown by the already-mentioned Maguelone grave 2187. This grave belongs to the earliest female inhumations dressed after north Pontic traditions in coastal Narbonensis, together with Estagel 118. The presence of these early dresses enables the identification of a kind of northern appendix for the Via Domitia-based region (maybe an independent clothing region?), formed by finds at Routier, Molandier-Bénazet, Le Vernet-Le Mouraut and Toulouse. It is recognisable only before $500 \mathrm{AD}$, their defining elements being both north Pontic combinations with crossbow brooches and middle-Danube inspired dresses with pairs of radiated bow brooches. A cruciform brooch produced in Anglo-Saxon Britain found at Castelnaudary, dating from the second half of the fifth century (Barrière-Flavy 1892, P1. IV.2), could be related to this group of cemeteries: it would outline a certain presence of northwest elements in a milieu dominated by north Pontic and middle-Danube traditions of clothing. Among the main features of this group of cemeteries north of the Via Domitia, however, we should list the disappearance of clothes inspired in an eastern barbarian fashion about 500 AD. Judging from the available evidence, especially at Bénazet and Le Mouraut, people had abandoned Ponto-Danubian types of clothing by the beginning of the sixth century.

At Estagel and Maguelone, we can observe the evolution undergone by north Pontic dress styles along the Via Domitia. The data available on both cemeteries, although limited, is remarkably homogeneous: Estagel grave 117 and Maguelone grave 2212, both lying close to earlier graves after the north Pontic fashion, were furnished with pairs of small radiated bow brooches dating from the late fifth century or the early sixth century (Lantier 1949, p.56, Fig. 2; Legrand-Garnotel 2004, Fig. 59). In Maguelone, mid-and-late sixth-century graves in the same cemetery section confirm the adoption of middle-Danube dress traditions with pairs of radiated bow brooches.

\section{II}

PARADE OF SHIELDS AT THE CROSSROADS OF GERMANIC CULTURES 


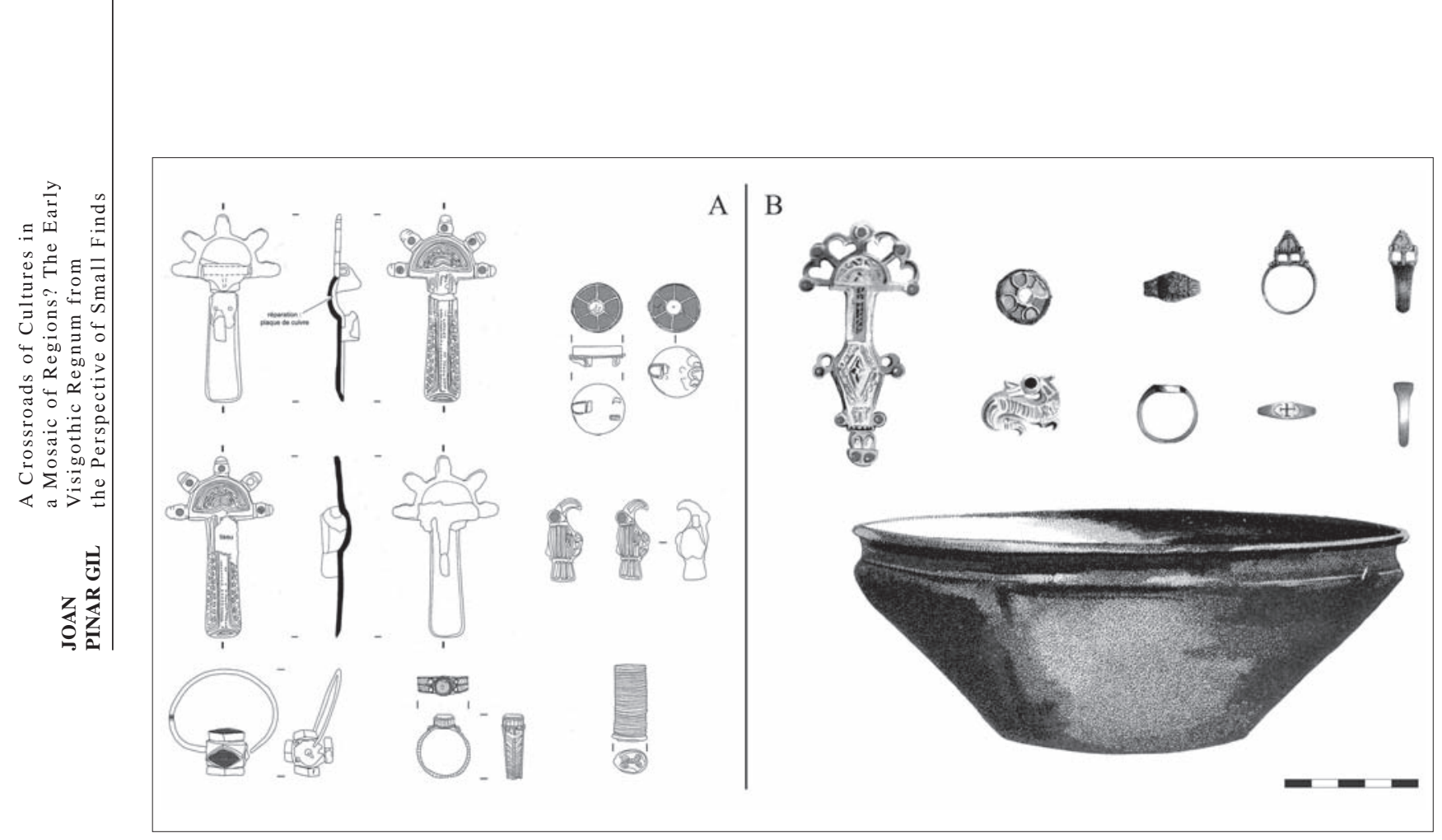

Fig. 10. Examples of sixth-century female clothes furnished with six brooches: A Chasseneuil-sur-Bonnieure, grave 87; B Herpes, grave unearthed on 15 June 1890 (after Poignant 2010; Delamain 1891).

Let me finish this short overview of the dress regions within the territory of the Visigothic kingdom by referring to another region with specific clothing features in northern Aquitania II, in the present-day départements of Charente and Charente-Maritime. Here the difficulties are bigger, because of the extremely fragmentary knowledge on the main sites of the region, such as the cemeteries of Herpes and Biron. As has already been seen, the first is a somewhat special case, characterised by a remarkable presence of objects originating in Anglo-Saxon Britannia. They appear frequently from the late fifth and early sixth centuries to the end of the second third of the sixth century (Soulat 2009, pp.188-197). Broadly contemporaneously, a significant number of radiated bow brooches finding their best counterparts in northern Gaul and the Rhine region are recorded in the cemetery (Delamain 1892, Pl. VI.23; XIII.84-86; XIV.91-93; Stutz 2003, Pl. 5761). Nevertheless, before that 'northwestern horizon' came, Danubian finds were preeminent in the site: this is pointed to by the mid-fifth century Prša-Levice and Carnuntum-Oslip inspired brooches from Herpes. This evolution pattern, as far as the data available enables an assertion, seems to be repeated in other cemeteries in this region. Thus, at Biron we can find Merovingian radiated bow brooches and bird brooches dating from the late fifth century onwards (Stutz 2003, nos. 817, 838). Nevertheless, before $500 \mathrm{AD}$, the picture seems to be dominated by finds connected with middle-Danube or north Pontic traditions, such as small Blechfbeln and the rest of a composite belt buckle (Maurin 1999, Fig. 72). A similar interpretation might be giv- en to the crossbow brooch found in the repeatedly used grave 484 at Chadenac, where later elements of Merovingian female clothes have also been identified (Mornais 2000, p.98). The recently researched cemetery at Chasseneuil-sur-Bonnieure may be one of the clearest examples of this tendency: by the third quarter of the fifth century, we can mention a pair of brooches from grave 89, which mix elements of Western BullesLauriacum-Sindelfingen brooches and middle-Danube Prša-Levice ones. By the beginning of the sixth century, we may mention grave 87 , where a woman wore a composite cloisonné belt buckle without any fibula, a type of dressing that is widespread in some other territories of the Visigothic regnum. Over this first inhumation, a second burial was made. It contained a combination of elements typical of northern Gaul: radiated bow brooches with trapezoidal foot, cloisonné disc brooches and bird-shaped brooches, dating from the late fifth century or the first third of the sixth century (Poignant 2010, pp.174-176). Its stratigraphical position places it after $500 \mathrm{AD}$, giving a precise date for the beginning of the 'merovingisation' of dress in that region. Grave 94 in the same cemetery, another clear example of Merovingian-style female clothing (Poignant 2010, Fig. 3), can be dated roughly to the same time span. Isolated graves and stray finds connected with sixth-century Merovingian dress found at Asnières-laGiraud, Criteuil-la-Magdeleine, Roullet-St. Estephe, Ronsenac and Saintes fit the same pattern (Stutz 2003).

Even if deeply influenced by Merovingian fashion, this clothing region will keep some extent of its personality: here we must mention the grave unearthed 
on 15 June 1890 at Herpes, and grave 87 at Chasseneuil-sur-Bonnieure, with combinations consisting of six brooches (Fig. 10), and the grave at Asnières-laGiraud, containing five brooches (Delamain $1891 \mathrm{Pl}$. VIII.44, XIII.24, XV.102; Poignant 2010, Fig. 3; Dangibeaud 1895-96). Although known occasionally in the Merovingian area, such combinations are rare outside northern Aquitania II.

\section{Conclusions}

This brief survey points out the importance of two still insufficiently researched aspects of Visigothic period funerary archaeology. They both help us to reconstruct a general picture dominated by multicultural and heterogeneity.

The multiplicity of traditions which shaped clothing in the early Visigothic West is recognisable already from the earliest times. The importance of the various cultural components differs from region to region, even if a common yet heterogeneous substrate can be reconstructed during the mid-and-late fifth century. Regional differences become more evident during the sixth century, showing sharply distinguishable developments which concern both clothing and funerary practices. In one region, Charente, the impact of the changing historical circumstances should be considered as a partial explanation for the changes in clothing type. For the rest, no comparable factor could be claimed: we are certainly dealing here with a slow transformation of material culture and social praxis.

Thus, the picture of a mosaic of regions helping to shape distinct funerary and clothing cultures that is evoked in the title seems to suit the situation as outlined nowadays by archaeology.

\section{Acknowledgements}

The results presented in this article were enabled by a research stay at the Department of the Early Middle Ages of the Römisch-Germanisches Zentralmuseum in Mainz, supported by a Marco Polo Programme scholarship awarded by the Department of Archaeology of the University of Bologna.

\section{References}

\section{Literature}

ÅBERG, N., 1922. Die Franken und Westgoten in der Völkerwanderungszeit. Uppsala-Leipzig-Paris.

BALDINI, I., 1999. L'oreficeria nell'Impero di Costantinopoli tra IV e VII secolo. Bari: Edipuglia.
BARRIÈRE-FLAVY, C., 1892. Étude sur les sépultures barbares du Midi et de l'Ouest de la France : industrie wisigothique. Toulouse: P.E. Privat.

BIERBRAUER, V., 1980. Frühgeschichtliche Akkulturationsprozesse in den germanischen Staaten am Mittelmeer (Westgoten, Ostgoten, Langobarden) aus der Sicht des Archäologen. In: Longobardi e Lombardia: aspetti di civiltà longobarda. Atti del $6^{\circ}$ Congresso Internazionale di Studio Sull'alto Medioevo. Spoleto, 89-105.

BIERBRAUER, V., 1994. Archäologie und Geschichte der Goten vom 1.-7. Jahrhundert. Frühmittelalterliche Studien, 28, 51-171.

BOUISSET, P., 1973. Note d'information sur la découverte de sépultures d'époque visigothique à Ouveillan (Chambard). Bulletin de la Commission Archéologique de Narbonne, 35, 201-204.

CATALÁN, R., ROJAS, J.M., 2010. La necrópolis de Boadilla (Illescas). Aspectos funerarios y contexto cronocultural de un asentamiento de época visigoda (siglos V-VII). In: J. PINAR, T. JUÁREZ, eds. Contextos funeraris a la Mediterrània nord-occidental (segles V-VIII). Gausac, 3435 [2009]. Sant Cugat del Vallès, 223-236.

CATALO, J., CALLEDE, F., DAYRENS, O., GENEVIEVE, V., PAYA, D., STUTZ, F., SOUQUET-LEROY, I., 2008. Commune de Vernet. Le Mouraut. Cimetière mérovingien et carolingien (Haute-Garonne, Midi-Pyrénées). Vol. 2 : Annexes et catalogue des tombes. Rapport final d'opération de l'INRAP.

CAZES, J.-P., 2009. La nécropole de Bénazet (Molandier, Aude) : un témoignage archéologique sur les variations de la frontière entre royaumes wisigoth et franc, Ve-VIIe siècles. Archéo 66, 23, 69-70.

DANGIBEAUD, Ch., 1895-96. Un nouveau cimetière mérovingien à marquer sur la carte de notre département : Asnières. Recueil de la Commission des Arts et Monuments de la Charente Inférieure, XIII, 268-269.

DELAMAIN, Ph., 1892. Le cimetière d'Herpes (fouilles et colection Ph. Delamain). Angoulême: L. Coquemard.

EBEL-ZEPEZAUER, W., 2000. Studien zur Archäologie der Westgoten vom 5.-7. Jh. n. Chr. Iberia Archaeologica, 2. Mainz.

LEGRAND-GARNOTEL, A., 2004. L'île de Maguelone du IIIe au XIIIe siècle. Thèse de Doctorat, Université de Provence Aix-Marseille 1.

HERNANDEZ, J., 2001. Le mobilier métallique de parure du haut Moyen Âge en Septimanie et ses parallèles septentrionaux et méditerranéens. Mémoire de DEA, Université Sorbonne-Panthéon - Paris III.

HOPKALO, O.V., 2011. Čoloviče ta žinoče černjahivs'ke vbrannja. Arheologija, 2, 17-34.

JAMES, E., 1977. The merovingian archaeology of SouthWest Gaul. BAR International Series, 25. Oxford.

KAZANSKI, M., 1994. À propos de quelques types de fibules germaniques de l'époque des Grandes Migrations trouvées en Gaule au Sud de la Loire. Antiquités Nationales, 26, 161-175.

KAZANSKI, M., 1998: Les fibules germaniques orientales et danubiennes en Gaule (périodes $\mathrm{C}_{2}-\mathrm{D}_{2}$ ). In: J. KUNOW, ed.. 100 Jahre Fibelformen nach Oscar Almgren. Forschungen zur Archäologie im Land Brandenburg, 5. Wünsdorf, 375-386.

LANTIER, R., 1943. Le cimetière wisigothique d'Estagel (fouilles de 1935 et 1936). Gallia, I, 153-188.

LANTIER, R., 1949. Le cimetière wisigothique d'Estagel (Pyrénées-Orientales). Fouilles en 1946, 1947 et 1948. Gallia, VII, 55-80.

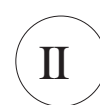

PARADE OF SHIELDS AT THE CROSSROADS OF GERMANIC CULTURES 
LÓPEZ QUIROGA, J., 2010. Arqueología del mundo funerario en la Península Ibérica (siglos $V$ al $X$ ). Madrid: La Ergástula.

MARTIN, M., 1991. Zur frühmittelalterlichen Gürteltracht der Frau in der Burgundia, Francia und Aquitania. In: L'art des invasions en Hongrie et en Wallonie. Mariemont, 3184.

MASSENDARI, J., 2006. La Haute-Garonne (hormis le Comminges et Toulouse). Carte Archéologique de la Gaule, 31/1. Paris.

MASTYKOVA, A., 2007. Le costume féminin de la civilisation de Černjahov avec des fibules en tôle métallique. In: J. TEJRAL, ed. Barbaren im Wandel. Beiträge zur Kulturund Identitätsumbildung in der Völkerwanderungszeit Spisy Archeologického Ústavu AV ČR Brno, 26. Brno, 201-217.

MAURIN, L., 1999. La Charente-Maritime. Carte Archéologique de la Gaule, 17/1. Paris.

MOLINERO, A., 1948. La necrópolis visigoda de Duratón (Segovia). Excavaciones del Plan Nacional de 1942 y 1943. Acta Arqueológica Hispánica, IV. Madrid.

MOLINERO, A., 1971. Aportaciones de las excavaciones y hallazgos casuales (1941-1959) al Museo Arqueológico de Segovia. Excavaciones Arqueológicas en España, 72. Madrid.

MORNAIS, P., 2000. Le mobilier funéraire mérovingien de la nécropole de "La Chapelle» à Chadenac (Charente-Maritime). Mémoire de maîtrise, Université de Bourgogne.

PAYA, D., 2010. Aux portes de Toulouse, le cimitière mérovingien et carolingien du Mouraut (Vernet, HauteGaronne). In: J. PINAR, T. JUÁREZ, eds. Contextos funeraris a la Mediterrània nord-occidental (segles V-VIII) Gausac, 34-35 [2009]. Sant Cugat del Vallès, 273-291.

PINAR, J., 2010a. Les tombes de femme à fibules en tôle dans l'Ouest (ca. 500) : dispersion, chronologie, origine et interprétation. Un état de la question. In: L. BOURGEOIS ed. Wisigoths et Francs : autour de la bataille de Vouillé (507). Recherches récentes sur le haut Moyen Âge dans le Centre-Ouest de la France. Actes des XXVIII Journées Internationales d'Archéologie Mérovingienne. Mémoires de l'AFAM, XXII. Saint-Germain-en-Laye, 23-40.

PINAR, J., 2010b. Sobre les tombes femenines amb presència de fíbules laminars a Hispania (segles V-VI): precisions tipològiques i cronològiques a un article recent. In: J. PINAR, T. JUÁREZ, eds. Contextos funeraris a la Mediterrània nord-occidental (segles V-VIII). Gausac, 34-35 [2009]. Sant Cugat del Vallès, 45-57.

PINAR, J., 2010c. Chlamys e cingulum nel tardo V secolo: tre rinvenimenti dall'Emilia Romagna. In: I. BALDINI, A.L. MORELLI, eds. L'oreficeria in Emilia Romagna dall'età romana al medioevo. Ornamenta, 2. Bologna, 229-256.

PINAR, J., 2011. Ponto-Danubian traditions of dress in early Visigothic Hispania: chronology, dissemination, contexts and evolution. In: V. IVANIŠEVIĆ V., M. KAZANSKI, eds. The Pontic-Danubian realm in the period of the Great Migration. Paris-Belgrade, 259-292.

PINAR, J., forthcoming. A note on female dressing in $5^{\text {th }}$ century southern Gaul. In: T. VIDA, ed. Romania Gothica II. The frontier world: Romans, barbarians and the military culture. Budapest.

PINAR, J., 2012. Un gruppo poco studiato di fibule di epoca gota: produzione, circolazione, utenti. In: I. BALDINI, A.L. MORELLI, eds. Luoghi, artigiani e modi di produzione nell'oreficeria antica. Ornamenta, IV. Bologna, 119141.
PINAR, J., RIPOLL, G., 2007. Männergräber in Aquitanien, Septimanien und Hispanien (ca. 450-520). Neue Überlegungen. Acta Praehistorica et Archaeologica, 39, 69-96.

PINAR, J., TURELL, L.G., 2007. Ornamenta vel vestimenta ex sepulchro abstulere. Reflexiones en torno a la presencia de tejidos, adornos y accesorios de indumentaria en el mundo funerario del Mediterráneo tardoantiguo. Collectanea Christiana Orientalia, 4, 127-167.

POIGNANT, S., 2010. Chasseneuil-sur-Bonnieure (Charente) : la nécropole Saint-Saturnin. In: L. BOURGEOIS, ed. Wisigoths et Francs : autour de la bataille de Vouillé (507). Recherches récentes sur le haut Moyen Âge dans le Centre-Ouest de la France. Actes des XXVIII Journées Internationales d'Archéologie Mérovingienne. Mémoires de l'AFAM, XXII. Saint-Germain-en-Laye, 171-182.

QUAST, D., 1999. Garnitures de ceintures méditerranéennes à plaques cloisonnées des Ve et début VIe siècles. Antiquités Nationales, 31, 233-250.

RIPOLL, G., 1985. La necrópolis visigoda de El Carpio de Tajo (Toledo). In: Excavaciones Arqueológicas en España, 142. Madrid.

RIPOLL, G., 1991. La ocupación visigoda en época romana a través de sus necrópolis (Hispania). Col.lecció de Tesis Microfitxades de la UB, 912. Barcelona.

RIPOLL, G., 1998. The arrival of the Visigoths in Hispania: population problems and the process of acculturation. In: W. POHL, H. REIMITZ, eds. Strategies of Distinction. The Construction of Ethnic Communities, 300-800. Leiden, 153-187.

RIPOLL, G., 1999. Symbolic life and signs of identity in Visigothic times. In: P. HEATHER, ed. The Visigoths from the migration period to the seventh century: an ethnographic perspective. Studies in Historical Archeoethnology, 4. Woodbridge-San Marino, 403-431.

SASSE, B., 2000. «Westgotische» Gräberfelder auf der Iberischen Halbinsel am Beispiel der Funde aus El Carpio de Tajo (Torrijos, Toledo). In: Madrider Beiträge, 26. Mainz. SOULAT, J., 2009. Le matériel archéologique de type saxon et anglo-saxon en Gaule mérovingienne. Mémoires de l'AFAM, XX. Saint-Germain-en-Laye.

STUTZ, F., 2003. Les objets mérovingiens de type septentrional dans la moitié sud de la Gaule. Thèse de doctorat, Université Aix-Marseille I.

TARACENA, B., 1926. Excavaciones en diversos lugares de la provincia de Soria. In: Memorias de la Junta Superior de Excavaciones y Antigüedades, 5. Madrid.

TOULZE, P., TOULZE, R., 1983. Recherches archéologiques à Routier (Aude). Bulletin de la Société d'Études Scientifiques de l'Aude, LXXXIII, 51-56.

ZEISS, H., 1934. Die Grabfunde aus dem spanischen Westgotenreich. Germanische Denkmäler der Völkerwanderungszeit, II. Berlin-Leipzig.

Received: 10 February 2010; Revised: 20 April 2012; Accepted: 17 October 2012.

Joan Pinar Gil

Associació per la Recerca,

Estudi i Difusió en Antiguitat Tardana, c/ Castellví s/n

E-08172 Sant Cugat del Vallès (Barcelona)

Dipartimento di Archeologia

Università di Bologna

Piazza San Giovanni in Monte 2

I-40124 Bologna

E-mail: jpinarg@msn.com 
KULTŪRŲ SANKIRTA

AR REGIONŲ MOZAIKA?

ANKSTYVASIS VIZIGOTŲ

REGNUM IŠ MAŽŲ RADINIŲ

PERSPEKTYVOS

\section{JOAN PINAR GIL}

\section{Santrauka}

Šioje trumpoje apžvalgoje pabrěžiama dviejų iki šiol nepakankamai tyrinètų vizigotų laikotarpio laidosenos archeologijos aspektų svarba. Abu šie aspektai padeda rekonstruoti bendrą vaizdą, kuriame vyravo daugiakultūriškumas ir nevienalytiškumas (1-10 pav.).

Tradicijų sudètingumas, kuris formavo vizigočių moterų aprangą, atpažịstamas jau nuo ankstyvujų laikų. İvairūs kultūriniai komponentai skiria vieną regioną nuo kito, netgi jei bendras - vis dèlto heterogeniškas substratas, jis gali būti rekonstruojamas $\mathrm{V}$ a. vidurio ir pabaigos medžiagos pagrindu. Skirtumai, aiškiai liudijantys beišsiskiriančią regionų raidą, tampa ryškesni VI amžiuje. Šie skirtumai yra susiję tiek su apranga, tiek su laidosena. Viename regione - Charente - besikeičiančiu istorinių aplinkybių itaka iš dalies galima būtų paaiškinti aprangos tipų pokyčius. Likusiems regionams negalima pritaikyti lyginamojo veiksnio: tai susiję su lèta materialinès kultūros ir socialinès praktikos transformacija.

Vertė Rasa Banytė-Rowell 